\title{
DEVELOPING EMPLOYEE PERFORMANCE THROUGH LEADER MEMBER EXCHANGE, ORGANIZATIONAL COMMITMENT, AND JOB SATISFACTION WITH PATH CAREER AS MEDIATION
}

\author{
Wulandari Heppy ${ }^{\star}$, Amaliyah, Purwandaya Budhi \\ Trilogi University, Jakarta, Indonesia \\ *E-mail: heppywu42@gmail.com
}

\begin{abstract}
Human resources $(\mathrm{HR})$ is one of the factors that is very important for the company. HR is also a key that determines the development of the company. In essence, human resources in the form of people employed in an organization as a mobilizer, thinker and planner to achieve organizational goals. The availability of qualified and professional human resources will improve the quality of company performance. This study discusses about the influence of Leader Member Exchange, Employee Performance, Employee Job Satisfaction, Employee Career Level, Employee Performance, Organizational Commitment. This research is a quantitative study using the Structural Equation Model (SEM) as a test tool in knowing the effect of various internal and external factors. The approach used in this research is the Variance Based SEM approach. The result of this study is that Employee Performance have positive and significant impact to each of the variables used.
\end{abstract}

\section{KEY WORDS}

Member exchange, performance, job satisfaction, career level, organizational commitment.

Human resources $(H R)$ is a very important factor for companies. HR is also a key that determines the development of the company. In essence, human resources in the form of people employed in an organization as a mobilizer, thinker and planner to achieve organizational goals. The availability of qualified and professional human resources will improve the quality of company performance (Mangkunegara, 2013). To create a quality workforce so as to produce good performance, the role of the leader is needed, because the leader is a person who influences followers, so that followers voluntarily carry out organizational goals.

Leader-member exchange theory (Leader Member), often abbreviated as LMX, explains the process of making roles between leaders and subordinates and exchange relationships that develop over time (Yukl, 2012). LMX focuses on therelationship dyadic (two directions) between the leader and each of his followers which is an exchange relationship that aims to increase organizational success by creating a positive relationship between the leader and his followers. Leaders determine the direction by developing a vision of the future, then they unite people by communicating the vision so that it can inspire them to overcome various problems (Robbins \& Judge, 2008). Based on prior research LMX is the relationship between leaders and their followers in an organizational work unit. High quality LMX is characterized by mutual trust, desire, respect and mutual influence between leader members and the team (Casimir, 2016; Kartika and Suharmono, 2016).

Other factors that affect performance include organizational commitment, job satisfaction and career development (Robbins and Judge, 2008). Organizational commitment influences various important behaviors so that the organization functions effectively such as low turnover rates, high employee performance, low levels of absenteeism and a high sense of ownership of the place of work (organizational citizenship). While the high satisfaction with the work itself, cooperation, opportunity or promotion, supervisors and coworkers, the higher performance will be seen from the high punctuality of work, quantity of work, and quality. A clear career planning and development in an organization will be able to increase employee motivation in carrying out their work, thereby creating a sense of satisfaction in carrying out their work. 
With the explanation above, it can be said that factors related to performance include LMX, organizational commitment, job satisfaction and career development. Another thing in the study conducted, shows that LMX has a positive relationship with employee performance. While Kartika and Suharnomo (2016), Bakan et al., (2014), Khan (2012) found that LMX affects performance through job satisfaction and organizational commitment as a mediating variable, career paths will affect employee performance. Because employees will realize that to develop a career requires good performance to the company. These studies examine the relevance of LMX to organizational commitment, LMX to job satisfaction, LMX to career path, organizational commitment, job satisfaction to performance, job satisfaction to performance and career path to performance (Casirmir, 2016; Bhal et al., 2009 ; Lin and Ma, 2004). This study discusses the influence of Leader Member Exchange, Employee Performance, Employee Job Satisfaction, Employee Career Level, Employee Performance, Organizational Commitment. By using the Structural Equation Model (SEM) model, it can be seen the relationship between variables, as well as the nature of the relationship.

\section{LITERATURE REVIEW}

Theory of Leader-Member Exchange (LMX) was first introduced by Dansereau, Graen and Cahsman in 1975 and then reintroduced by Graen through his research in 1976. Dansereau, Graen and Casman explained that the Leader-Member Exchange (LMX) theory was theory that explains how interpersonal relationships develop between superiors and subordinates (Yukl, 2012). Leader-Member Exchange (LMX) is a process of interaction that occurs in two individuals and will continuously develop. The content scope of LeaderMember Exchange (LMX) consists of three things, namely, Leader (leader or superior), Follower (Subordinate) and Relationship (Interpersonal Relations) (Graen and Bien, 1995). Finally, the relationship approach between superiors and subordinates will explain how interpersonal relationships occur.

Leader exchange members have different approaches and effective superiors are determined by the quality of interaction between superiors and subordinates. While other approaches are not able to explain the uniqueness of every relationship that is built between superiors and subordinates. The four dimensions possessed by Exchange Member Leaders, namely Affect, Loyalty, Contributions, and Professional Respect.

Affects are defined as reciprocal affections between superiors and subordinates based on interpersonal interactions, not just interactions that relate to work or professional values. Affect occurs when superiors and subordinates enjoy their time together, which can then develop commitment and friendships. Then loyalty refers to the level where superiors and subordinates are loyal to each other and formally defined as the level where superiors and subordinates support each other's actions and character in public. While the contribution relates to how to get the job done and how much effort is done by superiors and subordinates to achieve common goals. While professional respect refers to the perception of the degree to which each of the superiors and subordinates builds a reputation within and outside the organization, demonstrating excellence in working.

This study uses Leader Member Exchange, Employee Performance, Employee Job Satisfaction, Employee Career Level, Employee Performance, Organizational Commitment. The purpose of this study was to determine the effect of Leader Member Exchange on Work Commitment, Job Satisfaction, Career Path, and Employee Performance.

\section{METHODS OF RESEARCH}

This section discusses the research methods used to determine the influence of Leader Exchange Members, Employee Performance, Employee Job Satisfaction, Employee Career Levels, Employee Performance, Organizational Commitment. This research is a quantitative study using the Structural Equation Model (SEM) as a test tool in knowing the effect of various internal and external factors. The approach used in this research is the Variance Based SEM approach. To analyze using VBSEM, the analysis is carried out in 
three stages, namely the suitability of the measurement model, the suitability of the structural model, and the suitability of the whole model. In the first stage of the match test is intended to evaluate generally the goodness of fit (GOF) between the data and the model. Researchers have developed several GOF or Goodness Of Fit Indices (GOFI) measures that can be used together or in combination. GOFI is grouped into 3 parts, namely absolute fit measures, incremental fit measures, and parsimonious fit measures. By using the SEM method, the total number of samples to be taken by all five or ten variables multiplied in this study the researcher chose 10 as a multiplier of the number of indicators, then $18 \times 10=180$ respondents. To obtain data as a discussion carried out by collecting, processing, and analyzing it. The technique used in data collection is to use a questionnaire.

Empirical Findings and Discussion of Research Results. The study began by using the Goodness of Fit (GOF) measurement results and then proceed with the results of hypothesis testing.

Table 1 - Summary of the Measurement Results of the Goodness of Fit

\begin{tabular}{cccc}
\hline Criteria & Value & Condition & Results \\
\hline \hline Chi $^{2}$ & $3.150,277$ & Closer to 0 & Poor Fit \\
RMSEA & 0,068 & $0,05<$ RMSEA $<0,08$ & Good Fit \\
AIC & $29.874,080$ & The Smaller the Better & Poor Fit \\
BIC & $30.483,322$ & The Smaller the Better & Poor Fit \\
CFI & 0,741 & $>0,90$ & Poor Fit \\
TLI & 0,730 & $>0,90$ & Poor Fit \\
SRMR & 0,093 & $<0,05$ & Poor Fit \\
\hline
\end{tabular}

It can be seen from above table that the value of Chi-Square in this study is $3.150,277$ or poor criteria (poor fit). However the Chi-square criteria cannot be used as a single measure of the overall model fit, because the Chi-Square value cannot be well calculated according to the model (Parashakti et al., 2016). In testing the other eligibility criteria, namely AIC, BIC, Chi-Square Value in this study was 3.150 .277 or in poor fit criteria. Chi-square criteria cannot be used as the sole measure of overall model fit, because Chi-Square values do not indicate model fit properly (Parashakti et al., 2016). In testing the other eligibility criteria, namely AIC, BIC, SRMR, CFI and TLI are included in the category of poor (poor fit). However, the RMSEA criteria are in the good category. If there are one or more parameters that are fit then the model is declared fit (Aryani \& Rosinta, 2010). In an empirical study, a researcher is not required to fulfill all the criteria of goodness of fit, but depends on the judgment of each researcher (Hair et al., 2010; Parashakti et al., 2016). On this basis, it can be concluded that the suitability of the predicted model with observational values meets the requirements. Thus the analysis can proceed to hypothesis testing.

Effect of Leader Member Exchange (LMX) on Organizational Commitment. Based on the picture above, it can be seen the loading factor of the exogenous variable (LMX) to the mediating variable (Organizational Commitment) has a positive value of 0.47 (standardized Beta). Because the path coefficient can be defined as a correlation number, if the value is changed to a coefficient of determination it will be $(0.472)=0.221$. This shows that the LMX variable as a whole has contributed to changes in Organizational Commitment of $22.1 \%$. To measure the significance of the LMX variable on Organizational Commitment, we can see the $z$ table with z-standardized requirements $>1.96$. It can be seen that the $z$-standardized value is 7.24 and is greater than 1.96. It can be concluded that the LMX variable has a positive and significant effect on the Organizational Commitment variable.

Table 2 - Leader Member Exchange (LMX) to Organizational Commitment Coefficient

\begin{tabular}{ccc}
\hline Coefficient & Unstandarized & Standarized \\
\hline \hline B & 0,300 & 0,470 \\
\hline
\end{tabular}

Thus the first hypothesis stating that "Leader Member Exchange positively influences Organizational Commitment", can be accepted. 
Leader Member Exchange (LMX) is a mutually influential relationship between superiors and subordinates, LMX does not see only the behavior of superiors or subordinates but rather emphasizes the quality of the relationship formed from the interaction of the two. In a company with a high level of LMX quality, a subordinate will get special attention and assistance from the leadership. In addition, employees who have good reciprocal work relationships with their superiors have a sense of comfort and security in the company where they work. Improving the quality of the relationship between superiors and subordinates will increase organizational commitment to employees.

Effect of Leader Member Exchange (LMX) on Job Satisfaction. Based on the picture above, it can be seen that the loading factor of the exogenous variable (LMX) to the mediating variable (job satisfaction) has a positive value of 0.38 (standardized Beta). Because the path coefficient can be defined as a correlation number, then if the value is changed to a coefficient of determination it will be $(0.382)=0.144$. This shows that the LMX variable as a whole has contributed to changes in job satisfaction by $14.4 \%$. To measure the significance of the LMX variable on job satisfaction, we can see the $z$ table with $z$ standardized requirements $>1.96$. It can be seen in the table above that a $z$-standardized value of 5.81 is obtained and is greater than 1.96. Then it can be concluded that the LMX variable has a positive and significant effect on the job satisfaction variable. Thus the second hypothesis which states that "Leader Member Exchange has a positive effect on job satisfaction", can be accepted.

Table 3 - Leader Member Exchange (LMX) to Work Satisfaction Coefficient

\begin{tabular}{ccc}
\hline Coefficient & Unstandarized & Standarized \\
\hline \hline B & 0,310 & 0,380 \\
Z & 4,610 & 5,810 \\
\hline
\end{tabular}

It is said that an employee feels satisfied with his relationship, both between superiors and fellow coworkers because managers are very cooperative in helping, and other colleagues often provide input at work. Job satisfaction depends on descriptions of fair outcomes, treatment and procedures. When individuals feel that the organization's processes and results are fair, trust develops, when trust emerges, the individual is willing to engage voluntarily in behaviors that exceed the requirements. A mature leadership relationship, superiors and subordinates experience reciprocal influence, extra contractual behavior, mutual respect and like to internalize the same goals.

Effect of Leader Member Exchange (LMX) on Career Level. Based on the picture above, it can be seen the loading factor of the exogenous variable (LMX) to the mediating variable (career path) has a positive value of 0.51 (standardized Beta). Because the path coefficient can be defined as a correlation number, then if the value is changed to a coefficient of determination it will be $(0.512)=0.260$. This shows that the LMX variable as a whole has contributed to changes in career path of $26.0 \%$. To measure the significance of the LMX variable on career path, we can see the $z$ table with $z$-standardized requirements> 1.96. It can be seen in the table above that a $z$-standardized value of 8.47 is obtained and is greater than 1.96. Then it can be concluded that the LMX variable has a positive and significant effect on the career path variable. Thus the third hypothesis which states that "Leader Member Exchange positively influences career path" can be accepted.

Table 4 - Leader Member Exchange (LMX) to Career Level Coefficient

\begin{tabular}{ccc}
\hline Coefficient & Unstandarized & Standarized \\
\hline \hline $\mathrm{B}$ & 0,420 & 0,510 \\
$\mathrm{Z}$ & 5,540 & 8,470 \\
\hline
\end{tabular}

Human resource management cannot be separated from the attitude of a leader in managing employees. The role of a leader in an organization does not only govern subordinates, but it requires a good relationship between superiors and subordinates to optimize the existing human resources. The development of employees refers to efforts and 
job satisfaction to improve the life of an organization or institution to be better by improving the quality of employee work. In general it can be said that an employee's level of education can reflect his intellectual abilities and the types of skills he has. It is common and common for the type and level of education of an employee to be used to measure and assess a person's abilities.

The Effect of Leader Member Exchange (LMX) on Employee Performance. Based on the picture above, it can be seen the loading factor of the exogenous variable (LMX) to the endogenous variable (Employee Performance) has a positive value of 0.23 (standardized Beta). Because the path coefficient can be defined as a correlation number, then if the value is changed to a coefficient of determination it will be $(0.232)=0.052$. This shows that the LMX variable as a whole has contributed to changes in Employee Performance of $5.2 \%$. To measure the significance of the LMX variable on Employee Performance, we can see the $z$ table with z-standardized requirements $>1.96$. It can be seen in the table above that a zstandardized value of 3.18 is obtained and is greater than 1.96. It can be concluded that the LMX variable has a positive and significant effect on the Employee Performance variable. Thus the fourth hypothesis stating that "Leader Member Exchange positively influences Employee Performance", can be accepted.

Table 5 - Leader Member Exchange (LMX) to Employee Performance Coefficient

\begin{tabular}{ccc}
\hline Coefficient & Unstandarized & Standarized \\
\hline \hline B & 0,200 & 0,230 \\
Z & 3,010 & 3,180 \\
\hline
\end{tabular}

Performance is the result of work achieved by an employee in carrying out work in accordance with the responsibilities given by the company. Good employee perceptions of organizational support for the quality of their work life will create a sense of indebtedness in themselves to the organization so that they will feel they have an obligation to pay for it. Employees who feel that they are supported by the organization will reciprocate and reduce the imbalance in the relationship by engaging in citizenship behavior. Leader Member Exchange (LMX) leadership system can produce reciprocity between individuals without the influence of social boundaries or strata. This is in accordance with the results of previous research which explains that Leader Member Exchange (LMX) has a positive and significant effect on performance. This shows that the higher the Leader Member Exchange, the higher the performance of the employees of PT Ponsel Jobs Indonesia. Leaders and supervisors who pay attention to make employees have a high morale towards the company (Herlambang, 2017).

Effect of Organizational Commitment on Employee Performance. Based on the picture above can be seen loading factor of endogenous variables (Organizational Commitment) to endogenous variables (Employee Performance) has a positive value of 0.18 (standardized Beta). Because the path coefficient can be defined as a correlation number, then if the value is changed to a coefficient of determination will be $(0.182)=0.032$. This shows that the variable Organizational Commitment as a whole has contributed to changes in Employee Performance of $3.2 \%$. To measure the significance of the Organizational Commitment variable on Employee Performance, it can be seen table $z$ with z-standardized requirements> 1.96 .

Table 6 - Organizational Commitment to Employee Performance Coefficient

\begin{tabular}{ccc}
\hline Coefficient & Unstandarized & Standarized \\
\hline \hline B & 0,250 & 0,180 \\
& 2,330 & 2,140 \\
\hline
\end{tabular}

It can be seen in the table above that a z-standardized value of 2.14 is obtained and is greater than 1.96. It can be concluded that the Organizational Commitment variable has a positive and significant effect on the Employee Performance variable. Thus the fifth 
hypothesis which states that "Organizational Commitment has a positive effect on Employee Performance", can be accepted.

Many things support for human resources to have good quality and performance, one of which is the commitment of the employees concerned to the company where they are. High employee commitment to the company will make their performance focused in accordance with what is set by the organization.

Effect of Job Satisfaction on Employee Performance. Based on the picture above, it can be seen loading factor from endogenous variables (Job Satisfaction) to endogenous variables (Employee Performance) has a positive value of 0.22 (standardized Beta). Because the path coefficient can be defined as a correlation number, if the value is changed to a coefficient of determination it will be $(0.222)=0.048$. This shows that the overall Job Satisfaction variable has a contribution to changes in Employee Performance of $4.8 \%$. To measure the significance of the variable Job Satisfaction on Employee Performance, it can be seen $z$ table with $z$-standardized requirements $>1.96$. It can be seen in the table above that a $z$-standardized value of 3.16 is obtained and is greater than 1.96. It can be concluded that the Job Satisfaction variable has a positive and significant effect on the Employee Performance variable. Thus the sixth hypothesis which states that "Job Satisfaction has a positive effect on Employee Performance", can be accepted.

Table 7 - Work Satisfaction to Employee Performance Coefficient

\begin{tabular}{ccc}
\hline Coefficient & Unstandarized & Standarized \\
\hline \hline $\mathrm{B}$ & 0,240 & 0,220 \\
$\mathrm{Z}$ & 3,020 & 3,160 \\
\hline
\end{tabular}

Job satisfaction is defined as a pleasant state or positive emotion resulting from an assessment of one's work or work experience. Job satisfaction can also affect the feeling of satisfaction with what has been obtained from work. Job satisfaction is also related to the achievement of work performance, and work performance will result in the award being considered higher. If the award is considered fair and adequate, employee job satisfaction will increase, so that it can have a good impact on employee performance.

Effect of Career Level on Employee Performance. Based on the picture above, it can be seen loading factor of endogenous variables (Career Path) on endogenous variables (Employee Performance) has a positive value of 0.34 (standardized Beta). Because the path coefficient can be defined as a correlation number, then if the value is changed to a coefficient of determination it will be $(0.342)=0.115$. This shows that the variable Career Level as a whole has contributed to changes in Employee Performance by $11.5 \%$. To measure the significance of the Career Level variable on Employee Performance, it can be seen that the $z$ table with $z$-standardized requirements $>1.96$. It can be seen in the table above, that a $z$-standardized value of 4.60 is obtained and is greater than 1.96 . Then it can be concluded that the Career Path variable has a positive and significant effect on the Employee Performance variable. Thus the seventh hypothesis which states that "Career Path has a positive effect on Employee Performance", can be accepted.

By paying attention to employee career development, it is expected that their performance results can be optimal. Employee performance is a translation of performance which means the work of an employee, a management process or an organization as a whole, where the results of the work must be demonstrated concretely and measurably (compared to predetermined standards). A career path can improve employees' skills, knowledge and experience of their work. Employees who have competence in their work will get the opportunity to follow the stages of a career path and will achieve a good career path.

Table 8 - Career Level to Employee Performance Coefficient

\begin{tabular}{ccc}
\hline Coefficient & Unstandarized & Standarized \\
\hline B & 0,370 & 0,340 \\
Z & 3,980 & 4,600 \\
\hline
\end{tabular}


Effect of Leader Member Exchange (LMX) on Employee Performance through Mediation of Organizational Commitment. Based on Sobel Test result, it can be seen that Organizational Commitment significantly mediated the impact of LMX to Employee Performance. This is proved by using $Z$ value of 2,329 (above $z$ value of 1,96), and probability value of 0,019 (below alpha value of 0,05 ). The mediate effect can be calculated by multiplying between coeficient of LMX to Organizational Commitment and coefficient of Organizational Commitment to Employee Performance, which is $0,47 \times 0,18=0,084(8,4 \%)$. Therefore, eighth hypothesis that stated "Leader Member Exchange has positive effect to Employee Performance mediated by Organizational Commitment", can be accepted.

Table 9 - Indirect impact through Organizational Commitment

\begin{tabular}{cccccc}
\hline Exogen Variable & Endogen Variable & Intervening Variable & Indirect Impact & $\mathrm{Z}$ & $\mathrm{P}$ \\
\hline \hline LMX & Employee Performance & Organizational Commitment & 0,084 & 2,329 & 0,019 \\
\hline
\end{tabular}

A leader must be aware of his position which is an example of all his behavior in the form of his personality or temperament, the quality or quantity of work and relationships with other fellow workers. One that must be considered by leaders is the quality of the relationship between leaders and employees. Exhange Leader Member leadership system in its application can produce feedback between individuals without being affected by social boundaries or strata. Leaders and employees can communicate regardless of seniority and position so that it can have a positive impact on the company. This is supported by previous research which shows that the direct effect of the Exchange Member Leader is more effective than the indirect effect of mediating Organizational Commitment on the performance of notary employees (Sudirjo, 2013).

The Influence of Leader Member Exchange (LMX) on Employee Performance through Job Satisfaction Mediation. Based on Sobel Test result, it can be seen that Work Satisfaction significantly mediated the impact of LMX to Employee Performance. This is proved by using $Z$ value of 2,782 (above $z$ value of 1,96), and probability value of 0,005 (below alpha value of 0,05 ). The mediate effect can be calculated by multiplying between coeficient of LMX to Work Satisfaction and coefficient of Work Satisfaction to Employee Performance, which is $0,38 \times 0,22=0,083(8,3 \%)$. Therefore, ninth hypothesis that stated "Leader Member Exchange has positive effect to Employee Performance mediated by Work Satisfaction", can be accepted.

Table 10 - Indirect impact through Work Satisfaction

\begin{tabular}{ccccccc}
\hline Exogen Variable & Endogen Variable & Intervening Variable & Indirect Impact & Z & P \\
\hline \hline LMX & Employee Performance & & Work Satisfaction & 0,083 & 2,782 & 0,005 \\
\hline
\end{tabular}

Basically, both superiors and subordinates need job satisfaction to be able to carry out the company's vision and mission. Therefore the leader is expected to be able to apply leadership techniques that are able to establish a good communication between superiors and subordinates. The relationship that develops between leaders and subordinates influences a variety of important factors, both for individuals and organizations for example such as commitment, performance and job satisfaction. Therefore the leader must be careful in building the quality of the relationship. This is supported by previous research which confirms that LMX has no direct effect on employee performance, LMX will affect performance if mediated by job satisfaction and employee involvement. This is because the relationship between superiors and employees is considered not good because the supervisors' attitude is not good in conveying tasks to subordinates (Suharmono \& Kartika, 2016).

The Effect of Leader Member Exchange (LMX) on Employee Performance through Career Level Mediation. Based on Sobel Test result, it can be seen that Career Level significantly mediated the impact of LMX to Employee Performance. This is proved by using $Z$ value of 4,042 (above $z$ value of 1,96 ), and probability value of 0,000 (below alpha value of 
0,05). The mediate effect can be calculated by multiplying between coeficient of LMX to Career Level and coefficient of Career Level to Employee Performance, which is $0,51 \times 0,34$ $=0,173(17,3 \%)$. Therefore, tenth hypothesis that stated "Leader Member Exchange has positive effect to Employee Performance mediated by Career Level", can be accepted.

Table 11 - Indirect impact through Career Level

\begin{tabular}{llllll}
\hline Exogen Variable & Endogen Variable & Intervening Variable & Indirect Impact & Z & P \\
\hline \hline LMX & Employee Performance & Career Level & 0,173 & 4,042 & 0,000
\end{tabular}

Ability-oriented leaders focus on developing employee skills to improve the quality of employee performance (Kohli et al., 1998). Leaders who have a capacity building orientation look more like coaches who focus on improving employee skills and abilities. Capabilityoriented leaders include specifying what needs to be done to effectively perform tasks to employees, monitor progress and provide employees with feedback that is appropriate to their abilities, which is able to increase a strong commitment to remain part of the organization and strive to improve performance as feedback given by employees on the role and attention given by their leaders.

\section{CONCLUSION}

This study aims to examine the influence of Leader Member Exchange, Employee Performance, Employee Job Satisfaction, Employee Career Level, Employee Performance, Organizational Commitment. The results of this study indicate that Exchange Leader Members have a positive and significant influence on Employee Performance through Job Satisfaction Mediation, Exchange Leader Members have a positive and significant influence on Employee Performance through Career Path Mediation.

\section{REFERENCES}

1. Bakan, I. (2014). "Effects of Job Satisfaction on Job Performance and Occupational Commitments". International Journal of Management \& Information Technology. Vol. 9.

2. Bhal, K. (2009). "Leader-member exchange and subordinate outcomes: test of a mediation model". Leadership \& Organization Development Journal. Vol. 30.

3. Casimir, G. (2016). "The Relationships Amongst Leaders Exchange, Perceived Organizational Support, Affective Commitment, And In-Role Performance". Leadership \& Organization Development Journal. Vol. 35. 2016.

4. Graen, GB, \& Bien, M. (1995). "Relationship-based approach to leadership: Development of leader-member exchange (LMX) theory of leadership over 25 years: Applying a multilevel multi-domain perspective". The Leadership Quarterly. Vol. 6. June 1995.

5. Kartika (2016). "The Effect of the Quality of Leader Member Exchange on Employee Performance with Job Satisfaction and Employee Engagement as Mediation Variables (Study at the Hotel Tegal Bahari Inn)". Diponegoro Journal of Management. Vol. 5.

6. Lin, C., \& Ma, HC (2004). "Effects of leader-member exchange, job satisfaction, and organizational commitment on diagnosing employee job performance using career stage as a moderator". Asia Pacific Management Review. Vol. 9. January 2004.

7. Khan, AH (2012). "Impact of job satisfaction on employee performance: An empirical study of autonomous Medical Institutions of Pakistan". Afr. J. of Business Manag. Vol. 6.

8. Mangkunegara, P. (2013). Evaluasi Kinerja Sumber Daya Manusia. Refika Aditama.

9. Robbins, SP, \& Judge, TA (2008). Perilaku Organisasi (Edisi ke-12). Salemba Empat.

10. Yukl, GK (2012). Leadership in Organizations ( ${ }^{\text {sth }}$ Edition). Dorling Kindersley: New Delhi. 